\title{
Enhancing The Learning Environment Of Nursing Students Through Interprofessional Collaboration
}

\author{
Suzanne J. Crouch, Chamberlain College of Nursing, USA \\ Laura Fillmore, Chamberlain College of Nursing, USA \\ Sharon L. Phelps, Chamberlain College of Nursing, USA \\ Eme Ukot, Chamberlain College of Nursing, USA
}

\begin{abstract}
The AACN position statement (1999) supports interprofessional collaboration. The development of innovative collaborative teaching methods within education may enhance the learning environment of students. Educational institutions utilize student evaluations as a method of listening to the voices of students, but research related to their use is limited. The purpose of this study was to explore the impact of interprofessional collaboration on nursing students' perceptions of the online learning environment. An innovative collaborative teaching methodology was developed using a variety of disciplines, including physicians, pharmacists, chiropractic physicians, and nurses.

Quantitative data analyses indicated a significant increase in student satisfaction with the online course as well as the online environment $p<0.05$ following the establishment of the collaborative teaching methodology. Qualitative analysis illustrated enhanced satisfaction among students following the institution of interprofessional collaboration.

Findings that view the learning environment through the lens of students' eyes have many implications, including increased student and faculty satisfaction with the teaching/learning experience and enhanced collaboration among healthcare professionals. In addition, results may impact the curriculum by identifying a multidisciplinary approach to nursing education as an important resource.

If we believe that students have a right to be active participants in their educational experiences, then we must give voice to their values, choices, concerns, and requests. A collaborative teaching methodology is one way to ensure that students' voices are heard and acted upon, and it was found to be an innovative solution in meeting enrollment demands and healthcare needs. Collaborative relationships within nursing practice and nursing education are essential in the preparation of future nurses.
\end{abstract}

Keywords: Interprofessional Collaboration; Collaborative Teaching

\section{INTRODUCTION}

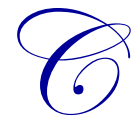

hallenges in healthcare are mirrored in challenges of healthcare education. A few of these are complexity in healthcare delivery, communication among team members, patient outcomes, prepared healthcare providers, and improved collaboration among the healthcare team. The educational challenges are complex content with limited time to instruct, communication among team members, student outcomes, prepared healthcare educators, and demands for collaboration among the healthcare team. These challenges create an environment which demands that innovative solutions be implemented. The solutions must meet accreditation requirements and provide students, faculty, and programs the opportunity for positive student 
outcomes. Innovative solutions are required to meet enrollment demands as well as the current and future healthcare needs. Collaborative relationships within nursing practice and nursing education are essential in the preparation of future nurses.

Finding prepared nursing faculty for a traditional campus-based school of nursing is limited by geography and available resources. In recent data by the American Association of Colleges of Nursing, the demand for nurse educators is ahead of the supply. Currently, there is a 7.8\% vacancy rate in nursing faculty for current enrollment. Many programs are turning away qualified students because they are unable to fill faculty positions to meet the demands (American Association of Colleges of Nursing, Nursing Faculty Fact Sheet, Oct, 24, 2012). The nursing faculty shortage is a risk to the needs of preparing a next generation of nurses. The American Association of Colleges of Nursing (AACN) position statement (1999) supports integration of ideas from nursing and other disciplines.

Development of innovative teaching and evaluation methods includes research in teaching strategies, course development and outcome evaluation, curricular and faculty evaluation innovations, research related to the knowledge and pedagogy of nursing, and creation of innovative learning environments that support diverse groups of students. Integrative scholarship requires participation from two or more disciplines in inquiry that advances knowledge across a wide range of techniques and methodologies. Works that would be recognized in the scholarship of integration in nursing include interfaces between nursing and a variety of disciplines. Integrative reviews of the literature, analysis of health policy, development of interdisciplinary educational programs and service projects, studies of systems in health care, original interdisciplinary research, and integrative models or paradigms across disciplines are examples of the scholarship of integration.

Interprofessional education is being recognized as a step to integrating professional practice during the education process for students entering a profession which includes interprofessional collaboration (Ketefian, Redman, Haucharunrnkul, Masterson, \& Neves, 2001). It is also recognized to be important in many professions, including those outside of healthcare, as important to the growth and development of professionals (Simon, Wee, Chin, Tindle, Guth, \& Mason, 2013). Recently, the National Council of State Boards of Nursing (2012) made recommendations for interprofessional education in nonclinical courses and supports the inclusion of interprofessional education in all nursing programs.

\section{Problem}

Required within baccalaureate nursing education are courses that can be considered sciences or nursing courses - pathophysiology and pharmacology. Both of these are foundational to other applied nursing courses that students encounter in the course of study. If the courses have a science designation, the content can be provided from any qualified person with deep knowledge of the content. If the course has a nursing designation, then it must be taught by a nurse licensed within the state the students reside. The requirements for nursing are more stringent and often limit the number of faculty qualified to teach. In an environment of a nursing faculty shortage, the requirements can impact course availability and also the strength of the course.

The interprofessional model of instruction is when a nursing course is taught by both a nursing faculty member and another healthcare professional (Dyer, 2003). Both educators have specific roles within the course as to avoid duplication of roles. The course modality is online with asynchronously instruction. The model places the nursing co-faculty as lead faculty providing both oversight, curricular design, and testing analysis to multiple sections of the online course. The non-nursing faculty provide day-to-day oversight of instruction in content assignments, discussion threads, and weekly feedback to students.

\section{Purpose}

Education institutions utilize student evaluations as a method to listen to the voices of students, but research related to their use is limited. The purpose of this nursing research study is to explore the impact of interprofessional collaboration on nursing students' perceptions of the online learning environment. 


\section{Theoretical Framework}

The concept of caring is foundational to nursing education regardless of the platform of delivery (Lerners \& Sitzman, 2006). Caring can be illustrated in modeling throughout the college of nursing in daily interactions one with another; the same is true for the online environment. This nursing research study was grounded on the theoretical framework based on the works of theorists Boykin and Schoenhofer (1993) and Boyer (1995).

Boyer (1995) suggests six essential qualities for a learning community to exist: (1) purpose, (2) communication, (3) discipline, (4) justice, (5) caring, and (6) celebration. Likewise, within the online environment, we are a community of persons coming together for a period of time with a specific purpose. Boyer further defines four dimensions of scholarship with nursing's traditional definition of scholarship. Boyer's concept can be utilized as a framework for the development of scholarship which includes discovery, integration, application, and teaching.

The first element of Boyer's model - discovery - encompasses traditional research. The element of discovery adds to the body of nursing knowledge and also contributes to the intellectual climate of the college of nursing. The second element - integration - focuses on making connections across disciplines whereby research can be translated into a larger body of knowledge and collaboration among professionals can occur (see Table 1). The third element - application - utilizes the findings of research as a problem-solving methodology for science as well as society. The last element - teaching - is viewed as an essential element of scholarship and the heart of education (Boyer, 1995).

Table 1: Boyer Model of Scholarship

\begin{tabular}{|l|l|l|}
\hline Type of Scholarship & \multicolumn{1}{|c|}{ Purpose } & \multicolumn{1}{c|}{ Measures of Performance } \\
\hline Discovery & $\begin{array}{l}\text { Build new knowledge through traditional } \\
\text { research. }\end{array}$ & $\begin{array}{l}\text { Publishing in peer-reviewed forums } \\
\text { Producing and/or performing creative work } \\
\text { within established field } \\
\text { Creating infrastructure for future studies }\end{array}$ \\
\hline \multirow{5}{*}{ Integration } & $\begin{array}{l}\text { *Interpret the use of knowledge across } \\
\text { disciplines. }\end{array}$ & $\begin{array}{l}\text { Preparing a comprehensive literature review } \\
\text { Writing a textbook for use in multiple disciplines } \\
\text { *Collaborating with colleagues to design and } \\
\text { deliver a core course }\end{array}$ \\
\hline \multirow{3}{*}{ Application } & Aid society and professions in addressing \\
& problems. & $\begin{array}{l}\text { Serving industry or government as an external } \\
\text { consultant } \\
\text { Assuming leadership roles in professional } \\
\text { organizations } \\
\text { Advising student leaders, thereby fostering their } \\
\text { professional growth }\end{array}$ \\
& & $\begin{array}{l}\text { Advancing learning theory through classroom } \\
\text { research } \\
\text { Developing and testing instructional materials } \\
\text { Mentoring graduate students } \\
\text { Designing and implementing a program-level } \\
\text { assessment system }\end{array}$ \\
\hline
\end{tabular}

Boykin and Schoenhofer (1993) developed the theory Nursing as Caring. The essence of Nursing as Caring is listening to the voices of students, as well as patients, in understanding that which is most important to them. In nursing education, speaking with the student's voice is a professional responsibility that becomes the catalyst for expanding the body of nursing knowledge as it relates to enhancing the learning environment for nursing students. According to Boykin and Schoenhofer (2001), authentic presence may be understood simply as one's intentionally being there with another in the fullness of one's personhood. Authentic presence may initiate and sustain caring in nursing situations. An incredible opportunity exists whereby nurse educators can be pioneers in the development and establishment of collaborative online learning communities. Embracing a nursing theoretical framework grounded in caring science may enhance learning and satisfaction within the online environment for both faculty and students.

The nurse educator must be committed to listening to the voices of students regarding their values, choices, concerns, and requests. Giving voice to all students and faculty empowers nurse educators to improve the learning 
environment, and a healthy environment exists and serves as a partnership in linking the providers and recipients of education in a way that has never existed previously.

\section{METHODOLOGY}

This study used a mixed method design to collect and analyze the qualitative and quantitative data. The rationale for using this method was to ensure that the trends and details of this study were captured, which may not have been possible with just a qualitative or quantitative study by itself. According to Creswell (2005), combining both qualitative and quantitative methods not only help understand the research problem better, but they complement each other and ensure a complete analysis of the data.

Each course had two faculty members - a nursing faculty and a non-nursing faculty who were both directly involved in the education of the undergraduate nursing students. The nursing faculty member was a Registered Nurse with a Masters or Doctoral degree, while the co-faculty member had expertise in another healthcare field and consisted of physicians, chiropractors, and pharmacists. For purposes of this study, the two-member team is known as the interprofessional team.

Each member of the interprofessional team had weekly responsibilities:

- The nursing faculty member was responsible for examination preparation, examination administration, examination statistics, examination reviews and, if necessary, grade revisions based on the exam statistics.

- $\quad$ The co-faculty member's responsibilities included the day-to-day operations of the course, such as the discussion posts, the content questions, responding to student emails specific to the course content, and the grading of all other classroom assignments.

In preparation for their role, each co-faculty had to attend and participate in a two-week online faculty orientation program which was led by the online Faculty Manager. The nursing faculty was also instrumental in the co-faculty member's success, assisting and working collaboratively post-orientation in preparing the course for incoming students. Team meetings were scheduled and held regularly. Some meetings consisted of nursing faculty from multiple course sections, while other meetings consisted of both nursing faculty and co-faculty.

\section{Design}

To address the paucity of literature on the impact of interprofessional collaboration on nursing students' perceptions of the online learning environment, this study employed both a qualitative and quantitative methodology. A quantitative descriptive and an experimental correlational design formed the basis for the quantitative aspect of this study, while a qualitative analysis was used to identify satisfaction among students following their online learning experience.

A quantitative research, according to Burns and Grove (2010), is a method used to examine relationships among variables, describe variables, and determine a cause-and-effect relationship between variables. Creswell (2005) noted that qualitative research is an effective methodology, especially relevant to projects that focus on participants' perceptions.

In this study, a survey approach using a Likert-styled questionnaire with open-ended questions was utilized. Data collection took place over a 12-month period from July 2011 to July 2012. The convenience sample included 394 nursing students who were enrolled in a Pathophysiology class as a requirement of a pre-licensure baccalaureate degree program. IRB approval was obtained for this study.

\section{Multidisciplinary Team}

An innovative collaborative teaching methodology was developed which utilized a variety of disciplines, including physicians, pharmacists, chiropractic physicians, and nurses, to teach in the Pathophysiology course. As identified by Peters and Waterman (1982), the mark of excellence in an organization is the extent to which a system 
of shared core values is in place - values that extend beyond technical requirements and transform the organization into a viable, dynamic institution which, for this particular prelicensure nursing program, has been accomplished through the TEACH value.

Devry Inc. and Chamberlain College of Nursing, in striving to accomplish their vision and meet the needs of their students, created the TEACH acronym, also known as TEACH values (Devry, 2013). These are values that are known, understood, shared, and integrated into the online learning environment.

The acronym TEACH stands for:

Teamwork and Communication

Engage Our Colleagues

Accountability + Integrity $=$ Ownership

Continuous Improvement

Help Our Students Achieve Their Goals

Devry's best practices and the TEACH values utilized in all Chamberlain College of Nursing courses were instrumental to the university being cited as one of eight model institutions in the new McKinsey \& Company report (Devry, 2010). The TEACH values focus on best practices created to enhance students' learning experiences and provide excellent nursing education. Educators work as members of a multidisciplinary team, they learn from each other, take responsibility/ownership, and strive for continuous improvements using evidence-based practice to drive decisions (Devry, 2013).

\section{Instrument}

During the last two weeks of courses at Chamberlain, online students are invited to complete a course evaluation to provide both quantitative and qualitative feedback related to the course and instructors. Students are notified of survey availability via email and an announcement placed within the learning management system (LMS) that houses the online courses. The survey link provided takes the student to a secure website outside of the LMS. Students are informed that their participation is voluntary and will not impact their success within the course.

The survey consists of 26 questions related to three components of the online learning experience - the online course itself, the instructor teaching the online course, and the environment in which the online course is delivered. Student responses are obtained using a 4-point Likert-styled scale for 23 items and open-ended questions for the remaining three items.

Items contained in the survey section related to the online course included questions about the textbook used, communication of course requirements, content presentation, workload, quality of materials used, grading of assignments, overall satisfaction with the course, and likelihood that the student will recommend this course to others. On the 4-point Likert-styled scale provided, positive responses received a high number with the wording varying so that answers matched the questions (see Appendix).

\section{Participants}

Participants consisted of a convenience sample of nursing students $(n=394)$ who were enrolled in a prelicensure baccalaureate degree program. The participants voluntarily completed an end-of-course survey available during the final two weeks of an online pathophysiology course in which they were enrolled. The number of students completing the course in the two sessions prior to the implementation of interdisciplinary collaborative teaching equaled 110 with 43 completing the end-of-course survey. In the four sessions following the implementation of interdisciplinary collaborative teaching, 284 students completed the courses with 102 submitting the end-of-course survey (see Table 2). 
Table 2: Students Response Rate

Pathophysiology NR281

\begin{tabular}{|l|c|c|c|c|c|c|}
\hline & Students & $\begin{array}{c}\text { Returned } \\
\text { Surveys }\end{array}$ & $\begin{array}{c}\text { Return } \\
\text { Rate }\end{array}$ & $\begin{array}{c}\text { Course Evaluation } \\
\text { Mean }\end{array}$ & $\begin{array}{c}\text { Faculty Evaluation } \\
\text { Mean }\end{array}$ & $\begin{array}{c}\text { Environment Evaluation } \\
\text { Mean }\end{array}$ \\
\hline 11-Jul & 110 & 43 & $39 \%$ & 2.77 & 3.19 & 2.65 \\
\hline 11-Nov & 116 & 35 & $30 \%$ & 3.38 & 3.36 & 3.45 \\
\hline 12-Mar & 168 & 67 & $39 \%$ & 3.59 & 3.63 & 3.56 \\
\hline
\end{tabular}

\section{Data Analysis}

An integrative methodology using a quantitative descriptive and an experimental correlational design formed the basis for the quantitative aspect of this study. The Statistical Package for Social Sciences (SPSS) was used for data analysis. Descriptive and correlational analyses were conducted on the data collected and all data were stored in a computerized database. The t-test and Chi square test were used to assess the correlation between the student evaluations prior to and following implementation of interprofessional collaboration. Levene's tests for equality of variances were conducted to assess the internal consistency of the measurement scales and all data.

The qualitative data from the student evaluations was analyzed using thematic analysis to identify common themes and place them into larger categories (Polit \& Beck, 2007). Qualitative analysis revealed major themes identifying enhanced satisfaction among students following the institution of interprofessional collaboration (see Table 3).

Table 3: Common Themes Identified Upon Qualitative Analysis

\begin{tabular}{|c|c|}
\hline Themes & Students' Quotes \\
\hline $\begin{array}{l}\text { Increase in student satisfaction with the course following the } \\
\text { establishment of the collaborative teaching methodology }\end{array}$ & $\begin{array}{l}\text { This was my first online Chamberlain course and I loved it. } \\
\text { I thought the class was very interesting yet challenging. I } \\
\text { liked that there were two instructors who kept the class } \\
\text { interesting and flowing. } \\
\text { The instructors were professional and very helpful. I } \\
\text { especially liked the case study. I think it was helpful to apply } \\
\text { the nursing concepts we learned to a patient we created. } \\
\text { I really liked how the class was set up. I thought the concept } \\
\text { of sharing the content questions with the class was very } \\
\text { helpful in preparing for the exam. } \\
\text { This was probably the best online experience so far. The case } \\
\text { studies were great and again the best part was the feedback } \\
\text { they gave. The instructors were very interactive. }\end{array}$ \\
\hline $\begin{array}{l}\text { Increase in student satisfaction with the faculty teaching the } \\
\text { online course following the collaborative teaching } \\
\text { methodology }\end{array}$ & $\begin{array}{l}\text { Both instructors appear to be interested in students learning } \\
\text { the material and applying it to nursing practice versus } \\
\text { presenting us with material and not caring if we learn the } \\
\text { material or not. } \\
\text { I really enjoyed the two instructors and wish I could take } \\
\text { them for other courses. } \\
\text { I had an awesome instructor who cared about my success. } \\
\text { Both instructors were extremely helpful, as each of their } \\
\text { comments truly helped clarify any misunderstandings I had } \\
\text { about complicated topics. } \\
\text { I learned a lot because she makes sure we are not only } \\
\text { learning but researching and applying nursing interventions } \\
\text { which challenges me to use my critical thinking skills. }\end{array}$ \\
\hline
\end{tabular}


Table 3 cont.

\begin{tabular}{|c|c|}
\hline & $\begin{array}{l}\text { My two instructors were both instructors who were very } \\
\text { involved in the discussion threads. Each student's post was } \\
\text { responded to by one of the instructors which provided } \\
\text { immediate feedback and kept the discussion from becoming } \\
\text { redundant. }\end{array}$ \\
\hline $\begin{array}{l}\text { Increase in student satisfaction with the online learning } \\
\text { environment following the establishment of the collaborative } \\
\text { teaching methodology }\end{array}$ & $\begin{array}{l}\text { The site was easy to use and well set up. } \\
\text { I was surprisingly impressed with the online course. I do not } \\
\text { usually take classes online (unless I have to) and I was upset } \\
\text { when I found out the class was online but I have found the } \\
\text { instructors to be very helpful and understanding. I can email } \\
\text { the instructors or any technical support staff for help. I am } \\
\text { new to the computer age since starting college a few years } \\
\text { ago but I have been able to navigate through this course with } \\
\text { the help of the professors. } \\
\text { Online classroom is very easy to use. } \\
\text { I only had one technical problem the entire session. It was } \\
\text { quickly resolved by the helpdesk and the professor. Great } \\
\text { system! } \\
\text { I was hesitant to take this course online, but I have found that } \\
\text { it is like being in the classroom when you have two } \\
\text { instructors who are thorough and active. }\end{array}$ \\
\hline
\end{tabular}

\section{Quantitative Data Analysis}

Student evaluation questions used for this analysis, and rated on the scale of $1=$ Not at all satisfied; $2=$ Dissatisfied; 3 = Satisfied; 4 = Extremely Satisfied, are:

- What is your overall satisfaction with this course? - Course overall satisfaction (OS)

- What is your overall satisfaction with this instructor? - Instructor overall satisfaction (OS)

- What is your overall satisfaction with your experience with the online classroom for this course? Environment overall satisfaction (OS) (see Table 4).

Table 4: Overall Satisfaction with the Course, Instructor, and Environment

\begin{tabular}{|l|c|c|c|}
\hline \multicolumn{1}{|c|}{ Groups } & Mean of CourseOS & Mean of InstructorOS & Mean of EnvironmentOS \\
\hline Pre & 2.77 & 3.19 & 2.65 \\
Post & 3.23 & 3.35 & 3.15 \\
\hline
\end{tabular}

Student responses were categorized into two groups: Pre (prior to the implementation of the interprofessional teaching model and Post (following the implementation of the interprofessional teaching model), as defined below:

- $\quad$ Pre - All students who took the first course in pathophysiology prior to implementation of the interprofessional teaching model (Summer $2011 \mathrm{~A}$ )

- $\quad$ Post - All students who took the first course in pathophysiology after the implementation of interprofessional teaching model (Fall 2011 A and Spring 2012 A)

T-tests were computed to examine if the means were significantly different for Course Overall Satisfaction prior to and following the implementation of interprofessional collaboration (see Table 5). The results were significant at $p>0.05$. In addition, Levene's Tests for equality of variances and t-tests for Equality of Means were conducted (see Table 6). The results were significant at $p>0.05$. 
Table 5: T-test for Course Overall Satisfaction (OS)

\begin{tabular}{|l|c|c|c|c|c|}
\hline & Group & N & Mean & Std. Deviation & Std. Error Mean \\
\hline \multirow{2}{*}{ CourseOS } & Pre & 43 & 2.767 & .7819 & .1192 \\
\cline { 2 - 7 } & Post & 102 & 3.225 & .7299 & .0723 \\
\hline
\end{tabular}

Table 6: Levene's Test for Equality of Variances and T-test for Equality of Means for Course Overall Satisfaction (OS)

\begin{tabular}{|c|c|c|c|c|c|c|c|c|c|c|}
\hline & \multicolumn{2}{|c|}{$\begin{array}{c}\text { Levene's Test for } \\
\text { Equality of } \\
\text { Variances }\end{array}$} & \multicolumn{7}{|c|}{ t-test for Equality of Means } \\
\hline & & \multirow[t]{2}{*}{$\mathbf{F}$} & \multirow[t]{2}{*}{ Sig. } & \multirow[t]{2}{*}{$\mathbf{t}$} & \multirow[t]{2}{*}{ df } & \multirow[t]{2}{*}{$\begin{array}{l}\text { Sig. (2- } \\
\text { tailed) }\end{array}$} & \multirow[t]{2}{*}{$\begin{array}{c}\text { Mean } \\
\text { Difference }\end{array}$} & \multirow[t]{2}{*}{$\begin{array}{l}\text { Std. Error } \\
\text { Difference }\end{array}$} & \multicolumn{2}{|c|}{$\begin{array}{l}95 \% \text { Confidence } \\
\text { Interval of the } \\
\text { Difference }\end{array}$} \\
\hline & & & & & & & & & Lower & Upper \\
\hline \multirow{2}{*}{ CourseOS } & $\begin{array}{l}\text { Equal variances } \\
\text { assumed }\end{array}$ & .020 & .889 & -3.379 & 143 & .001 & -.4580 & .1356 & -.7260 & -.1901 \\
\hline & $\begin{array}{l}\text { Equal variances } \\
\text { not assumed }\end{array}$ & & & -3.285 & 74.361 & .002 & -.4580 & .1394 & -.7358 & -.1803 \\
\hline
\end{tabular}

Result: $p<0.05$ which is significant

T-tests were computed to examine if the means were significantly different for Instructor Overall Satisfaction prior to and following the implementation of interprofessional collaboration (see Table 7). The results were not significant at $p>0.05$. In addition, Levene's Tests for equality of variances and t-tests for Equality of Means were conducted (see Table 8). The results were not significant at $p>0.05$.

Table 7: T-test for Instructor Overall Satisfaction (OS)

\begin{tabular}{|l|c|c|c|c|c|}
\hline & Education Group & $\mathbf{N}$ & Mean & Std. Deviation & Std. Error Mean \\
\hline \multirow{2}{*}{ InstructorOS } & Pre & 43 & 3.186 & .6988 & .1066 \\
\cline { 2 - 7 } & Post & 102 & 3.353 & .6986 & .0692 \\
\hline
\end{tabular}

Table 8: Levene's Test for Equality of Variances and T-test for Equality of Means for Instructor Overall Satisfaction $(\mathrm{OS})$

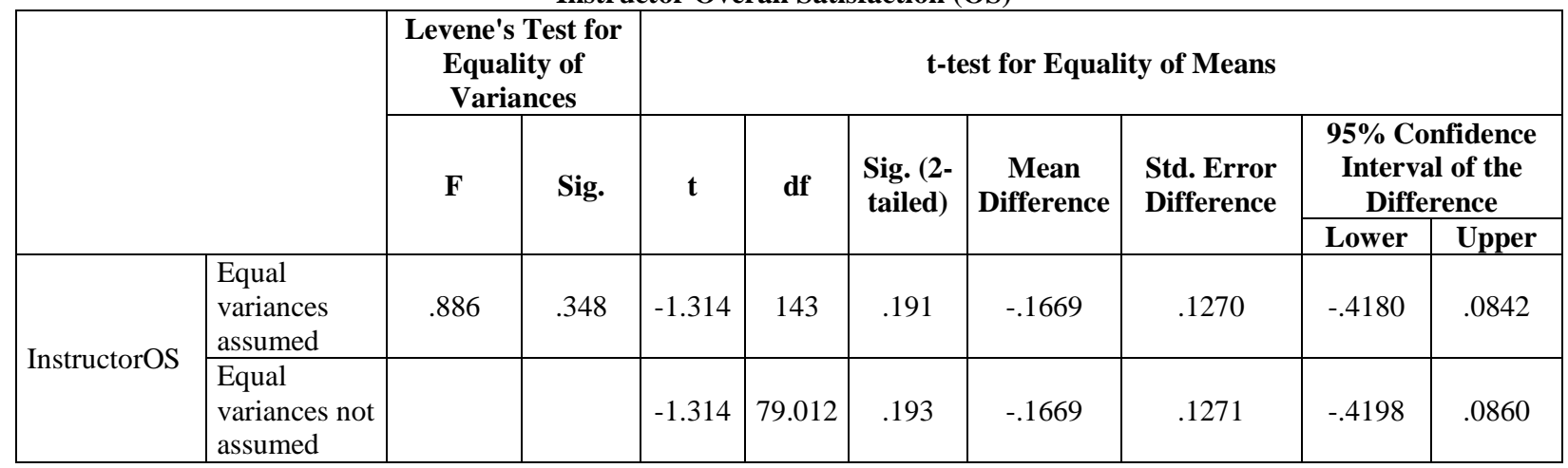

Result: $p>0.05$ which is not significant

T-tests were computed to examine if the means were significantly different for Environment Overall Satisfaction prior to and following the implementation of interprofessional collaboration (see Table 9). The results were significant at $p>0.05$. In addition, Levene's Tests for equality of variances and t-tests for Equality of Means were conducted (see Table 10). The results were significant at $p>0.05$.

Table 9: T-test for Environment Overall Satisfaction (OS)

\begin{tabular}{|l|c|c|c|c|c|}
\hline & Education Group & N & Mean & Std. Deviation & Std. Error Mean \\
\hline \multirow{2}{*}{ EnvironmentOS } & Pre & 43 & 2.651 & 1.0439 & .1592 \\
\cline { 2 - 7 } & Post & 102 & 3.147 & .8605 & .0852 \\
\hline
\end{tabular}


Table 10: Levene's Test for Equality of Variances and T-test for Equality of Means for Environment Overall Satisfaction (OS)

\begin{tabular}{|c|c|c|c|c|c|c|c|c|c|c|}
\hline & \multicolumn{2}{|c|}{$\begin{array}{c}\text { Levene's Test } \\
\text { for Equality of } \\
\text { Variances }\end{array}$} & \multicolumn{7}{|c|}{ t-test for Equality of Means } \\
\hline & & \multirow[t]{2}{*}{$\mathbf{F}$} & \multirow[t]{2}{*}{ Sig. } & \multirow[t]{2}{*}{$\mathbf{t}$} & \multirow[t]{2}{*}{ df } & \multirow[t]{2}{*}{$\begin{array}{l}\text { Sig. (2- } \\
\text { tailed) }\end{array}$} & \multirow[t]{2}{*}{$\begin{array}{c}\text { Mean } \\
\text { Difference }\end{array}$} & \multirow[t]{2}{*}{$\begin{array}{l}\text { Std. Error } \\
\text { Difference }\end{array}$} & \multicolumn{2}{|c|}{$\begin{array}{l}\text { 95\% Confidence } \\
\text { Interval of the } \\
\text { Difference }\end{array}$} \\
\hline & & & & & & & & & Lower & Upper \\
\hline \multirow{2}{*}{ EnvironmentOS } & $\begin{array}{l}\text { Equal } \\
\text { variances } \\
\text { assumed }\end{array}$ & 4.743 & .031 & -2.970 & 143 & .003 & -.4959 & .1669 & -.8259 & -.1659 \\
\hline & $\begin{array}{l}\text { Equal } \\
\text { variances not } \\
\text { assumed }\end{array}$ & & & -2.746 & 67.218 & .008 & -.4959 & .1806 & -.8563 & -.1355 \\
\hline
\end{tabular}

Result: $p<0.05$ which is significant

For the next analysis, the four levels of student responses were further categorized into two groups as follows:

$1=$ Not at all satisfied

$2=$ Dissatisfied

$3=$ Satisfied

$4=$ Extremely satisfied

Student responses 1 and 2 were grouped into the "Not satisfied" category and student responses 3 and 4 were grouped in the "Satisfied" category. Chi-Square tests were computed for both not satisfied with the course and satisfied with the course prior to and following the implementation of interprofessional collaboration (see Tables 11 and 12). Results were significant at $p<0.05$.

Table 11: Chi-Square for Course Overall Satisfaction (OS)

\begin{tabular}{|c|c|c|c|c|}
\hline & \multicolumn{2}{|c|}{ Education Group } & \multirow{2}{*}{ Total } \\
\hline & & Pre & Post & \\
\hline \multirow{2}{*}{ CourseOS } & Not Satisfied & 13 & 14 & 27 \\
\hline & Satisfied & 30 & 88 & 118 \\
\hline \multicolumn{2}{|l|}{ Total } & 43 & 102 & 145 \\
\hline
\end{tabular}

Table 12: Advanced Chi-Square Tests for Course Overall Satisfaction (OS)

\begin{tabular}{|c|c|c|c|c|c|}
\hline & Value & df & Asymp. Sig. (2-sided) & Exact Sig. (2-sided) & Exact Sig. (1-sided) \\
\hline Pearson Chi-Square & $5.439^{\mathrm{a}}$ & 1 & .020 & & \\
\hline Continuity Correction $^{\mathrm{b}}$ & 4.404 & 1 & .036 & & \\
\hline Likelihood Ratio & 5.104 & 1 & .024 & & \\
\hline Fisher's Exact Test & & & & .034 & .020 \\
\hline Linear-by-Linear Association & 5.402 & 1 & .020 & & \\
\hline $\mathrm{N}$ of Valid Cases & 145 & & & & \\
\hline
\end{tabular}

a. 0 cells $(.0 \%)$ have expected count less than 5 . The minimum expected count is 8.01 . b. Computed only for a $2 \times 2$ table. Result: $p<0.05$ which is significant

Student responses 1 and 2 were grouped into the "Not satisfied" category and student responses 3 and 4 were grouped in the "Satisfied" category. Chi-Square tests were computed for both not satisfied with the instructor and satisfied with the instructor prior to and following the implementation of interprofessional collaboration (see Tables 13 and 14). Results were not significant at $p<0.05$. 
Table 13: Chi-Square Tests for Instructor Overall Satisfaction (OS)

\begin{tabular}{|l|c|c|c|c|}
\hline \multicolumn{2}{|c|}{} & \multicolumn{2}{c|}{ Education Group } & \multirow{2}{*}{ Total } \\
\cline { 3 - 5 } \multicolumn{2}{c|}{ InstructorOS } & Pre & 9 & 14 \\
\hline Total & Not Satisfied & 5 & 93 & 131 \\
\cline { 2 - 5 } & Satisfied & 38 & 102 & 145 \\
\hline
\end{tabular}

Table 14: Advanced Chi-Square tests for Instructor Overall Satisfaction (OS)

\begin{tabular}{|c|c|c|c|c|c|}
\hline & Value & df & Asymp. Sig. (2-sided) & Exact Sig. (2-sided) & Exact Sig. (1-sided) \\
\hline Pearson Chi-Square & $.273^{\mathrm{a}}$ & 1 & .602 & & \\
\hline Continuity Correction $^{b}$ & .046 & 1 & .830 & & \\
\hline Likelihood Ratio & .264 & 1 & .607 & & \\
\hline Fisher's Exact Test & & & & .759 & .403 \\
\hline Linear-by-Linear Association & .271 & 1 & .603 & & \\
\hline $\mathrm{N}$ of Valid Cases & 145 & & & & \\
\hline
\end{tabular}

a. 1 cells $(25.0 \%)$ have expected count less than 5 . The minimum expected count is 4.15 . b. Computed only for a $2 \times 2$ table. Result: $p>0.05$ which is not significant

Students responses 1 and 2 were grouped into the "Not satisfied" category and student responses 3 and 4 were grouped in the "Satisfied" category. Chi-Square tests were computed for both not satisfied with the environment and satisfied with the environment prior to and following the implementation of interprofessional collaboration (see Tables 15 and 16). Results were significant at $p<0.05$.

Table 15: Chi-Square for Environment Overall Satisfaction (OS)

\begin{tabular}{|l|c|c|c|c|}
\hline \multirow{2}{*}{} & \multicolumn{2}{|c|}{ Education Group } & \multirow{2}{*}{ Total } \\
\cline { 3 - 5 } EnvironmentOS & Not Satisfied & 15 & 17 & 32 \\
\cline { 2 - 5 } & Satisfied & 28 & 85 & 113 \\
\hline Total & 43 & 102 & 145 \\
\hline
\end{tabular}

Table 16: Advanced Chi-Square Tests for Environment Overall Satisfaction (OS)

\begin{tabular}{|l|c|c|c|c|c|}
\hline & Value & df & Asymp. Sig. (2-sided) & Exact Sig. (2-sided) & Exact Sig. (1-sided) \\
\hline Pearson Chi-Square & $5.837^{\text {a }}$ & 1 & .016 & & \\
\hline Continuity Correction ${ }^{\text {b }}$ & 4.825 & 1 & .028 & & \\
\hline Likelihood Ratio & 5.523 & 1 & .019 & & .027 \\
\hline Fisher's Exact Test & & & & & \\
\hline Linear-by-Linear Association & 5.796 & 1 & .016 & & \\
\hline N of Valid Cases & 145 & & & & \\
\hline
\end{tabular}

a. 0 cells $(.0 \%)$ have expected count less than 5 . The minimum expected count is 9.49 . b. Computed only for a $2 \times 2$ table. Result: $p<0.05$ which is significant

\section{Data Analysis Summary}

The t-test and Chi square test were used to assess the correlation between the student evaluations prior to and following implementation of interprofessional collaboration. Levene's tests for equality of variances were conducted to assess the internal consistency of the measurement scales and all data. Results indicated that the overall student satisfaction rating with the pathophysiology online course was significant at the $p<0.05$ following the implementation of interprofessional collaboration. Results also indicated that the overall student satisfaction rating with the instructor teaching the course did not significantly increase following the implementation of interprofessional collaboration. This may be because prior to the implementation of the interprofessional model, the nursing faculty were teaching the course singularly and also continued to teach with a partner following the implementation of the interprofessional model. Lastly, results indicated that the overall student satisfaction rating with the pathophysiology online environment was significant at the $p<0.05$ following the implementation of interprofessional collaboration. 


\section{CONCLUSIONS}

This study explored the use of a multidisciplinary approach to nursing education in the online environment. Findings which view the learning environment through the lens of students' eyes have many implications. Implications for nursing education include enhanced collaboration among healthcare professionals and increased student and faculty satisfaction with their teaching/learning experience. Results of this nursing research study may impact the curriculum of nursing programs by identifying a multidisciplinary approach to nursing education as an important resource.

Student evaluations are a direct means of communication and serve as a method of staying in touch with the heart of education - the students. If we, as nurses, believe that students have a right to be active participants in their educational experiences, then we must give voice to their values, choices, concerns, and requests. A collaborative teaching methodology is one way to ensure that students' voices are heard and acted upon and it was found to be an innovative solution in meeting enrollment demands and healthcare needs. Collaborative relationships within nursing practice and nursing education are essential in the preparation of future nurses.

\section{AUTHOR INFORMATION}

Dr. Crouch graduated from Wright State University with a BSN in 1976 and MS in nursing in 1990. She earned a doctorate in education from Florida Atlantic University in 1999. She is an Advanced Registered Nurse Practitioner and board certified in Psychiatric Nursing. Dr. Crouch has publications in Maternal-Child Nursing, Nursing Education, Nursing Leadership, and the Acute Care Environment. Dr. Crouch has received recognition for her work through national and international consultations. She also has publications in the Virginia Henderson International Library, in affiliation with Sigma Theta Tau International. E-mail: suzannecrouch@aol.com (Corresponding author)

Dr. Fillmore has been a nurse for twenty nine years in all areas of adult health and in outpatient and inpatient settings. She has been a nursing educator in both academia and clinical settings for twelve years. Dr. Fillmore has been a nursing education administrator for the last eight years and currently is the Dean of Faculty at Chamberlain College of Nursing. She resides in Henderson, Nevada with her family. E-mail: 1fillmore@ chamberlain.edu

Ms. Phelps earned her BSN from Rockhurst University/Research College of Nursing in Kansas City, MO and a MS in Nursing from Southern Illinois University at Edwardsville in Edwardsville, IL. As curriculum manager, she is responsible for the creating and maintaining online course shells that support both online and on campus delivery of the prelicensure, baccalaureate-nursing curriculum at Chamberlain College of Nursing. She spends her non-work time with family and friends in eastern Missouri. E-mail: sphelps@chamberlain.edu

Dr. Ukot has been in healthcare since 1994, and holds a Bachelor of Science degree in Nursing, a Bachelor of Science degree in Management Information Technology, a Master's of Science in Nursing, an MBA in Healthcare Management, and a Doctor of Nursing Practice from Carlow University. Her clinical area of expertise is in Informatics, Adult Health, Emergency Nursing, Administration, Informatics, and Neurosciences. Dr. Ukot has presented both nationally and internationally on nursing education. E-mail: eukot@chamberlain.edu

\section{REFERENCES}

1. American Association of Colleges of Nursing. (1999). Position statement. Retrieved from http://www.aacn. nche.edu/publications/position/NsgResearch

2. American Association of Colleges of Nursing. (2012, Oct. 24). Nursing faculty fact sheet. Retrieved from http://www.aacn.nche.edu/media-relations/fact-sheets/nursing-faculty-shortage

3. Boyer, E. (1995). The basic school: A community for learning. Proceeds from Basic School Eastern Consortia. San Francisco, CA. Retrieved from http:www.jmyedu/basicschools/speech.shtml

4. Boykin, A., \& Schoenhofer, S. (1993). Nursing as caring: A model for transforming nursing practice. National League for Nursing Press. Boston: Jones and Bartlett.

5. Boykin, A., \& Schoenhofer, S. (2001). The role of nursing leadership in creating caring environments in health care delivery systems. Nursing Administration Quarterly, 25(3), 1-7. 
6. Burns, N., \& Grove, S. K. (2010). The practice of nursing research: Appraisal, synthesis and generation of evidence $\left(6^{\text {th }}\right.$ ed.). St. Louis: Saunders.

7. Chamberlain College of Nursing. (2011). Online course evaluation. Unpublished instrument.

8. Creswell, J. W. (2005). Educational research: Planning, conducting, and evaluating quantitative and qualitative research ( $2^{\text {nd }}$ ed.). Upper Saddle River, NJ: Pearson Education.

9. Devry (2013). About us: Purpose, vision and values. Retrieved from http://www.devryinc.com/aboutus.jsp

10. Dyer, J. (2003). Multidisciplinary, interdisciplinary, and transdisciplinary educational models and nursing education. Nursing Education Perspectives, July/August 2003, 24(6), 186-188.

11. Ketefian, S., Redman, R. W., Hanucharunrnkul, S., Masterson, A., \& Neves, E. P. (2001). The development of advanced practice roles: Implications in the international nursing community. International Nursing Review, 48(3), 152-163.

12. Lerners, K., \& Sitzman, D. W. (2006). Student perceptions of caring in online baccalaureate education. Nursing Education Perspective, 27(5), 254-9.

13. National Council of State Boards of Nursing (2012). Section III: Model rule revisions. Retrieved from https://www.ncsbn.org/3308.htm

14. Peters, T., \& Waterman, R. (1982). In search of excellence. New York: Harper \& Row.

15. Polit, D. F., \& Beck, C. T. (2007). Nursing research: Generating and assessing evidence of nursing practice. Philadelphia, PA: Lippincott, Williams, \& Wilkins.

16. Simon, G. L., Wee, B. S., Tindle, A. D., Guth, D., \& Mason, H. (2013). Synthesis for the interdisciplinary environmental sciences: Integrating systems approaches and service learning. Journal of College Science Teaching, 42(5), 42-49. 


\section{APPENDIX}

Online Course Evaluation Chamberlain College of Nursing (2011)

\begin{tabular}{|c|c|}
\hline Survey Item & Scale \\
\hline \multicolumn{2}{|l|}{ On-Line Course Questions } \\
\hline 1. What is your overall satisfaction with this course? & $\begin{array}{l}\text { Satisfaction Scale } \\
1=\text { Not at all satisfied } \\
2=\text { Dissatisfied } \\
3=\text { Satisfied } \\
4=\text { Extremely satisfied }\end{array}$ \\
\hline 2. How likely are you to recommend this course to others? & $\begin{array}{l}\text { Likelihood Scale } \\
1=\text { Not at all likely } \\
2=\text { Unlikely } \\
3=\text { Likely } \\
4=\text { Extremely likely }\end{array}$ \\
\hline \multicolumn{2}{|l|}{ Please respond to the following statements using the scale provided. } \\
\hline 3. The textbook supported my learning in the course. & \multirow{6}{*}{$\begin{array}{l}\text { Agreement Scale } \\
1=\text { Strongly Disagree } \\
2=\text { Disagree } \\
3=\text { Agree } \\
4=\text { Strongly Agree } \\
9=\text { Not applicable }\end{array}$} \\
\hline 4. The requirements of the course were clearly communicated. & \\
\hline 5. Presentation of content in the course stimulated my interest in the topics. & \\
\hline 6. The work load for this course was reasonable. & \\
\hline 7. I was satisfied with the quality of material in this course. & \\
\hline 8. The grading of assignments in this course was fair. & \\
\hline $\begin{array}{l}\text { 9. Please use the space below to provide Chamberlain College of Nursing with any other } \\
\text { feedback you would like regarding this course. }\end{array}$ & Open-end \\
\hline \multicolumn{2}{|l|}{ ONLINE INSTRUCTOR ITEMS } \\
\hline 10. What is your overall satisfaction with this instructor? & $\begin{array}{l}\text { Satisfaction Scale } \\
1=\text { Not at all satisfied } \\
2=\text { Dissatisfied } \\
3=\text { Satisfied } \\
4=\text { Extremely satisfied }\end{array}$ \\
\hline 11. How likely are you to recommend this instructor? & $\begin{array}{l}\text { Likelihood Scale } \\
1=\text { Not at all likely } \\
2=\text { Unlikely } \\
3=\text { Likely } \\
4=\text { Extremely likely }\end{array}$ \\
\hline \multicolumn{2}{|l|}{ Please respond to the following statements using the scale provided. } \\
\hline 12. The instructor's response to my introduction post made me feel welcome in the course. & \multirow{6}{*}{$\begin{array}{l}\frac{\text { Agreement Scale }}{1=\text { Strongly Disagree }} \\
2=\text { Disagree } \\
3=\text { Agree } \\
4=\text { Strongly Agree } \\
9=\text { Not applicable }\end{array}$} \\
\hline $\begin{array}{l}\text { 13. The instructor responded to my questions as per course policy ( } 24 \text { hours on week days } \\
\text { and } 48 \text { hours on weekends.) }\end{array}$ & \\
\hline 14. The instructor's feedback facilitated my learning. & \\
\hline 15. The instructor's communications each week made the focus for my work clear. & \\
\hline 16. The instructor was knowledgeable on the course subject matter. & \\
\hline 17. The instructor showed a sincere interest in my learning. & \\
\hline $\begin{array}{l}\text { 18. Please use the space below to provide Chamberlain College of Nursing with any other } \\
\text { feedback you would like regarding your instructor for this course. }\end{array}$ & Open-end \\
\hline \multicolumn{2}{|l|}{ ONLINE ENVIRONMENT ITEMS } \\
\hline $\begin{array}{l}\text { 19. What is your overall satisfaction with your experience with the online classroom for this } \\
\text { course? }\end{array}$ & $\begin{array}{l}\text { Satisfaction Scale } \\
1=\text { Not at all satisfied } \\
2=\text { Dissatisfied } \\
3=\text { Satisfied } \\
4=\text { Extremely satisfied }\end{array}$ \\
\hline $\begin{array}{l}\text { 20. How likely are you to recommend on-line courses at Chamberlain to others as a result of } \\
\text { taking this course? }\end{array}$ & $\begin{array}{l}\text { Likelihood Scale } \\
1=\text { Not at all likely } \\
2=\text { Unlikely } \\
3=\text { Likely } \\
4=\text { Extremely likely }\end{array}$ \\
\hline
\end{tabular}


Please respond to the following statements using the scale provided.

21. My level of computer skill was adequate for success in the course.

22. Links to resources for the course were easy to use.

23. Technical support was helpful in resolving any problem I encountered.

34. Navigation within the course was user-friendly.

25. Content displayed on my computer screen was easy to view.

Agreement Scale

$1=$ Strongly Disagree

$2=$ Disagree

$3=$ Agree

$4=$ Strongly Agree

26. Please use the space below to provide Chamberlain College of Nursing with any other feedback you would like regarding the online classroom for this course.

$9=$ Not applicable

Open-end 